\title{
Impact And Permeability Properties of Fibrous Triple Blended Self Compacting Concrete.
}

\author{
S.Vijaya Kumar $^{1}$ B.Deankumar ${ }^{2}$ B. L. P Swami ${ }^{3}$ \\ ${ }^{I}$ Associate Professor, Department Of Civil Engineering, Vasavi College of Engineering, Hyderabad, Telangana. \\ ${ }^{2}$ Professor, Department Of Civil Engineering, JNTU Hyderabad, Telangana. \\ ${ }^{3}$ Professor, Department Of Civil Engineering, Vasavi College Of Engineering, Hyerabad,Telangana.
}

\begin{abstract}
Abstrct: In the present experimental project, self-compacting concrete of M40 is tried using triple blended technique with condensed silica fume (CSF), as a partial replacement by weight of cement at percentage of $10 \%$ and fly ash at 20\%. Steel fibres having aspect ratio of 10,15, 20 and 25 are also used. The various proportions of steel fibres are added at $0 \%, 0.1 \%, 0.2 \%, 0.3 \%$ and $0.4 \%$ as percentages of the volume of concrete.The optimum replacement of cement by fly ash and condensed silica fume from which the result benefits strength and workability are studied. The specimens are tested for impact and RCPT.Based on the experimental results obtained in the present project work, conclusions are drawn on the improvement of strength properties of SCC by triple blending and employing fibres.
\end{abstract}

Keywords: Triple blending, steel fibres, impact, permeability, and optimum strength.

\subsection{Development of Self-Compacting Concrete}

\section{Introduction}

Development of self-compacting concrete(SCC) is a desirable achievement in the construction industry in order to overcome problems associated with cast-in place concrete. Self-compacting concrete (SCC) is an innovative concrete, does not require for placing and compaction. It is able to flow under its own weight completely filling the form work and achieving full compaction even in the presence of congested reinforcement. The hardened concrete is dense, homogeneous and has the same engineering properties and durability as traditional vibrated concrete.

It flows like "honey" and has a very smooth surface level after placing. With regard to its composition, self-compacting concrete consists of the same components as conventionally vibrated concrete, which are cement, aggregates, and water, with the addition of chemical and mineral admixtures in different propertions.Usually, the chemical admixtures used are high-range water reducers (super plasticizers) and viscosity-modifying agents, which can change the rheological properties of the concrete. Mineral admixtures are used as an extra fine material, besides cement and in some cases, they replace cement. In this study, the cement content was partially replaced with mineral admixtures e.g. fly ash, slag cement, and silica fume, admixtures that improve the flowing and strengthening characteristics of the concrete. The social problem on durability of concrete structures arose around 1983 in Japan. Due to gradual reduction in the number of skilled workers in Japan's construction industry, a similar reduction in the quality of construction work took place. As a result of this fact, one solution for the achievement of durable concrete structures independent of the quality of construction work was the employment of self-compacting concrete which could be compacted in to every corner of a form work, purely by means of its own weight. Studies to develop Self-compacting concrete, including a fundamental study on the workability of concrete, were carried out by researches Ozawa and Maekawa at university of Tokyo.

\subsection{Review of previous work}

The concept of self-compacting concrete was proposed in 1986 by professor Hajime Okamura $(1997)^{8}$,but the prototype was first developed in 1988 in Japan,by Professor Ozawa(1989) ${ }^{10}$ at the university of Tokyo. Self-compacting concrete was developed at that time to improve the durability of concrete structures. Since then, various investigations have been carried out and mainly large construction companies have used SCC in practical structures in Japan. Investigations for establishing a rational mix-design method and self-compacting testing methods have been carried out from the view point of making it as standard concrete. Self-compacting concrete is cast so that no additional inner or outer vibration is necessary for the compaction. EFNARC specifications describe the various flow requirements of SCC. 


\subsection{Details of The Present Study}

The present study deals with fibrous self-compacting concrete with triple blending. This triple blending includes the replacement of $20 \%$ of cement by fly ash and also replacement of $10 \%$ of cement by silica fume in every mix. Chemical admixtures like super plasticizer and viscosity modifying agent are also used for better flowability and workability. Workability tests like T50 and V-funnel tests are conducted as per EFNARC standards to satisfy the SCC requirements like flowability and workability. Percentage of fibre reinforcement is varied from 0.1 to 0.4 (in 4 stages). Aspect ratios of 10,15,20 and 25 are adopted for each percentage. The results of compressive strength impact strength are studied and correlated. The permeability of the mixes was tested.

\section{Experimental Investigation}

The details of the present experimental investigation are as follows.

\subsection{Materials.}

The following materials are employed in the present investigation

\subsubsection{Cement 53 grade}

Ordinary Portland cement of 53 grade of Ultra Tech brand was used and tested for physical and chemical properties as per IS: 4013-1988 and found to be confirming to various specifications of are 10269-1987.

\subsubsection{Fine aggregate}

In the present investigation, fine aggregate, natural river sand was obtained from local market. The physical properties of fine aggregate like specific gravity, bulk density, gradation and fineness modulus are tested in accordance with IS-2386.Its specific gravity is 2.62 and fineness modulus is 2.6. Robo sand of matching fineness is used as part replacement of river sand.

\subsubsection{Coarse aggregate}

The crushed granite aggregate of $10-12 \mathrm{~mm}$ maximum size was obtained from the local crushing point. The physical properties of coarse aggregate like specific gravity, bulk density, gradation, and fineness modulus are tested in accordance with IS -2386. Specific gravity is 2.6 and fineness modulus is 6.85

\subsubsection{Fly ash}

In the present investigation work, the TYPE-II fly ash was used as cement replacement material. It is obtained from Ramagundam thermal power station in Telangana. The specific surface of fly ash is found to be 4750 $\mathrm{cm}^{2} / \mathrm{gm}$ by Blaine's permeability apparatus.

\subsubsection{Condensed Silica Fume (CSF)}

CSF was obtained from M/S V.B.Ferro Alloys Ltd, Rudraram near Hyderabad. Its fineness was found more than $10,000 \mathrm{~cm}^{2} / \mathrm{gm}$.

\subsubsection{Viscosity Modifying Agent (VMA)}

The inclusion of VMA ensured the homogeneity and the reduction of the tendency of the highly fluid mix to segregate. Glenium-2 VMA of M/S BASF INDIA LTD. is used for this work. Performance fluctuations due to variation in the material quality and the moisture in aggregate are attenuated by the VMA making quality control easy.

\subsubsection{Super plasticizer}

Super plasticizer (B233 of M/S BASF INDIA LTD) was employed for the preparation of SCC.

\subsubsection{Steel fibres}

Mild steel fibres of $1 \mathrm{~mm}$ diameter were used at constant aspect ratios of 10, 15, 20 and 25. Percentage of fibre reinforcement is varied from 0.1 to 0.4 in four stages.

Table1:Properties of steel fibres

\begin{tabular}{|l|l|l|l|l|l|l|l|}
\hline $\begin{array}{l}\text { Properties of } \\
\text { Steel fibers }\end{array}$ & Type & $\begin{array}{l}\text { Density } \\
\left(\mathbf{k g} / \mathbf{m}^{\mathbf{3}}\right)\end{array}$ & $\begin{array}{l}\text { Elastic } \\
\text { Modulus } \\
(\mathbf{G P a})\end{array}$ & $\begin{array}{l}\text { Tensile } \\
\text { Strength } \\
(\mathbf{M p a})\end{array}$ & $\begin{array}{l}\text { Diameter } \\
\mathbf{m m}\end{array}$ & $\begin{array}{l}\text { Length } \\
\mathbf{m m}\end{array}$ & No of Fiber \\
\hline Steel & Steel wire & 7850 & 210 & 250 & 1 & 55 & $\begin{array}{l}\text { Mono } \\
\text { Filament }\end{array}$ \\
\hline
\end{tabular}

\subsubsection{Water}

This is least expensive but most important ingredient of concrete. The water which is used for making concrete should be clean and free from harmful impurities such as oil, alkali, acid, etc.The water which is fit for drinking is used for making concrete.

2.1.10 Robo sand

Robo sand was used as partial replacement to river sand, at $30 \%$ in the present investigation. 
Impact And Permeability Properties of Fibrous Triple Blended Self Compacting Concrete.

2.2 Concrete Mix Design For M40 Grade

Concrete mix of M40 grade was designed as per the guidelines of IS 10262-1909. The mix proportions and quantities of materials required for $1 \mathrm{~m}^{3}$ of concrete are given in table 2 and 2.3

Table 2.Concrete Mix Proportions

\begin{tabular}{|c|c|c|l|l|c|}
\hline $\begin{array}{l}\text { SL. } \\
\text { NO. }\end{array}$ & $\begin{array}{l}\text { CONCRETE } \\
\text { GRADE }\end{array}$ & CEMENT & $\begin{array}{l}\text { FINE } \\
\text { AGGREGATE }\end{array}$ & $\begin{array}{l}\text { COARSE } \\
\text { AGGREGATE }\end{array}$ & WATER/CEMENT \\
\hline 1 & M40 & 1 & 1.3 & 2.2 & 0.45 \\
\hline
\end{tabular}

Table3 .Quantities of Materials Required with Mineral Admixtures (20\% fly ash and 10\% CSF)

\begin{tabular}{|l|l|l|}
\hline SL.NO & MATERIALS REQUIRED & QUANTITIES IN KG PER m $^{3}$ for M40 \\
\hline 1 & CEMENT & 343.23 \\
\hline 2 & FLY ASH & 68.67 \\
\hline 3 & CSF & 45.78 \\
\hline 5 & FINE AGGREGATE & 549.45 \\
\hline 6 & COARSE AGGREGATE & 1013.87 \\
\hline
\end{tabular}

\subsection{Combinations:}

In the reference concrete mix M40,OPC was replaced by mineral admixtures of fly ash at $20 \%$ and CSF at 10\% which are found to be optimum dosages, This results in triple blended concrete. Steel fibers were added at percentages of $0.1,0.2,0.3$ and 0.4 . The aspect ratios were varied as $10,15,20$ and 25 . In total there are 18 combinations of triple blended fibrous concrete mixes.( Table 4).

\section{4 flow requirements}

In SCC flowability is the main criteria. Flowability is achieved with the help of superplasticizer and viscosity modifying agent. All the 18 numbers of mix combinations were tested for T50 slump flow, V-funnel flow, L-box and U-box requirements as per EFNARC specifications. The details of the tests are given in table-4. The mixes have satisfied the requirements.

\subsection{Casting and Curing}

Specimens of $150 \mathrm{~mm}$ diameter with $63.5 \mathrm{~mm}$ thickness were cast in required number for all the combinations to conduct impact test by drop hammer. To know the effect on permeability of various mixes, specimens of size $100 \mathrm{~mm}$ diameter and $50 \mathrm{~mm}$ height were cast 6 numbers for each mix for testing in the RCPT apparatus. All specimens were cured for 28 days before testing. Standared procedures were followed for casting and curing.

\subsection{TESTING}

\subsubsection{Impact test}

The impact specimens were tested by using the drop hammer test apparatus conforming to ACI 544.2R. As the specimens are of M40 mix and fibrous .they require several hundreds of drops by the hammer to fail. This procedure is tedious and time consuming. Instead, the specimens were given fixed number of blows like $0,50,100,150$ and 200, By this process, due to the energy transfer, some of the compressive strength capacity in the specimen is lost. As the number of blows given are increased the strength loss will also be more. Aftr giving the blows the specimen were tested for compressive strength and values were recorded.(Table 5).

\subsubsection{Rapid Chloride Permeability Test (RCPT)}

The RCPT apparatus consists of 12 number of cells to accommodate 12 number of concrete specimens ,each with a size of $150 \mathrm{~mm}$ diameter and $50 \mathrm{~mm}$ height. The apparatus conforms to ASTMC 1202. The RCPT method is the fastest method to determine the permeability of concrete. In this test by passing electrical current through concrete sample during 6 hour exposed period to sodium chloride solution, the coulomb number is noted. This number indicates the charge transferred during the test for the specimen. If the charge is more it indicates permeability is more for the sample. All the sample were subjected to the RCPT test and results are noted and shown in table 6.

\subsection{Presentations of the results}

\section{Discussion of The Results}

The drop hammer test results and RCPT test results are given in table 5 and 6 . The compressive strength after zero blows for a typical aspect ratio of 15 is plotted in bar chart for various fiber percentages as shown in fig1. The chloride ion permeability for various combinations is plotted by bar charts in fig2. 


\subsection{Workability of triple blended fibrous SCC.}

As seen from the results of workability (table 4) triple blending and presence of steel fiber are satisfying EFNARC specification for workability. By suitably adjusting the percentage of super plasticiser and VMA required workability can be obtained even with steel fiber reinforcement. Triple blending helps in more workability where as steel fibers reduce the workability. Hence in the case of fibrous SCC the percentage of steel fibers and the aspect ratio are to be controlled, to maintain the workability.

\subsection{Compressive Strength}

The specimens without undergoing the impact test (zero blows) were subjected to compression and ultimate strengths were recorded and are given in table 5. It can be seen from the table that as the aspect ratio of fiber increases its compressive strength of concrete is also increased. For example at $0.1 \%$ with an aspect ratio 25 , the compressive strength is increased by nearly 8 to $10 \%$. The trend is same with the remaining percentage of fibers also. With a percentage of $0.4 \%$ and aspect ratio of 25 there is an increase by nearly $35 \%$ in Compressive strength of concrete. Hence it is clear that percentage of steel and aspect ratio influence the compressive strength.

\subsection{Impact Strength}

It can be seen from table 5, that as number of blows in the drop hammer are increased the resulting compressive strength is getting decreased. For example at $0.2 \%$ steel with an aspect ratio of 15 , the compressive strength is reduced by nearly $3 \%, 5 \%, 10 \%$, and $30 \%$ with $50,100,150$ and 200 blows respectively. Hence, it is clear that impact strength is directly related to compressive strength and concrete which has received an impact, loses some of its compressive strength.

Table 3: Workability for different mixes of SCC

\begin{tabular}{|c|c|c|c|c|c|c|c|c|c|c|}
\hline $\begin{array}{l}\text { S.n } \\
\text { o }\end{array}$ & $\begin{array}{l}\text { MIX } \\
\text { NO. }\end{array}$ & $\begin{array}{l}\text { Fly } \\
\text { ash \% }\end{array}$ & $\begin{array}{l}\text { CSF } \\
\%\end{array}$ & $\begin{array}{l}\text { Fibre } \\
\text { Percenta } \\
\text { ge }\end{array}$ & $\begin{array}{l}\text { Aspect } \\
\text { Ratio }\end{array}$ & $\begin{array}{l}\text { T50cm } \\
\text { slump } \\
\text { flow }\end{array}$ & $\begin{array}{l}\text { V- } \\
\text { funnel }\end{array}$ & $\begin{array}{l}\text { L- } \\
\text { box }\end{array}$ & $\begin{array}{l}\text { U- } \\
\text { box }\end{array}$ & Remarks \\
\hline \multicolumn{6}{|c|}{ Limits as per EFFNARC SPECIFICATIONS- 2002} & $\begin{array}{l}\begin{array}{l}2-5 \\
(\mathrm{sec})\end{array}\end{array}$ & $\begin{array}{l}6-12 \\
\text { (sec) }\end{array}$ & $\begin{array}{l}\text { 0.8- } \\
1.0\end{array}$ & $\begin{array}{l}\text { 0- } \\
\text { 30 } \mathrm{mm}\end{array}$ & \multirow{19}{*}{$\begin{array}{l}\text { The SCC mix } \\
\text { satisfies the } \\
\text { EFNARC } \\
\text { Specification } \\
\text { s. }\end{array}$} \\
\hline 1 & IP(a) & $\mathbf{0 . 0}$ & $\mathbf{0 . 0}$ & $\mathbf{0 . 0}$ & $\mathbf{0 . 0}$ & 3 & 8 & 0.8 & 28 & \\
\hline 2 & $\mathbf{I P}(\mathbf{b})$ & 20 & 10 & $\mathbf{0 . 0}$ & $\mathbf{0 . 1}$ & 3.2 & 7 & $\mathbf{0 . 8 2}$ & 25 & \\
\hline 3 & IP1 & 20 & 10 & 0.1 & 10 & 4 & 7 & 0.8 & 20 & \\
\hline 4 & IP2 & 20 & 10 & 0.1 & 15 & 4.6 & 10 & 0.84 & 25 & \\
\hline 5 & IP3 & 20 & 10 & 0.1 & 20 & 3.34 & 6.2 & 0.86 & 28 & \\
\hline 6 & IP4 & 20 & 10 & 0.1 & 25 & 4.2 & 7 & 0.8 & 30 & \\
\hline 7 & IP5 & 20 & 10 & 0.2 & 10 & 3 & 6.5 & 0.82 & 24 & \\
\hline 8 & IP6 & 20 & 10 & 0.2 & 15 & 3.6 & 7 & 0.83 & 26 & \\
\hline 9 & IP7 & 20 & 10 & 0.2 & 20 & 4.2 & 10 & 0.82 & 28 & \\
\hline 10 & IP8 & 20 & 10 & 0.2 & 25 & 5 & 10.8 & 0.8 & 30 & \\
\hline 11 & IP9 & 20 & 10 & 0.3 & 10 & 3.56 & 8 & 0.85 & 25 & \\
\hline 12 & IP10 & 20 & 10 & 0.3 & 15 & 4.1 & 8.4 & 0.86 & 27 & \\
\hline 13 & IP11 & 20 & 10 & 0.3 & 20 & 4.5 & 9.2 & 0.84 & 30 & \\
\hline 14 & IP12 & 20 & 10 & $\begin{array}{l}0.3 \\
\end{array}$ & 25 & 4.8 & 11.1 & 0.82 & 30 & \\
\hline 15 & IP13 & 20 & 10 & 0.4 & 10 & 4.1 & 8.2 & 0.86 & 28 & \\
\hline 16 & IP14 & 20 & 10 & 0.4 & 15 & 4.3 & 9.6 & 0.84 & 27 & \\
\hline 17 & IP15 & 20 & 10 & 0.4 & 20 & 4.6 & 10.9 & 0.82 & 29 & \\
\hline 18 & IP16 & 20 & 10 & 0.4 & 25 & 4.9 & 11.5 & 0.8 & 30 & \\
\hline
\end{tabular}

\subsection{Correlations Between Impact Strength And Compressive Strength}

As already mentioned, the specimens after undergoing impact (number of blows by the drop hammer) are losing the compressive strength capacity and it is lower and lower with more and more number of blows. Hence a correlation exists between the number of blows and compressive strength for a given concrete mix with a given steel percentage and given aspect ratio.

\subsection{Results Of Rept}

Referring to table 6, it can be seen that the chloride ion permeability is reduced and has become from low to very low for various combinations. It is clear that the triple blended specimens without fiber have recorded very low range of permeability compared to reference concrete specimens. By resorting to triple blending, even compressive strength of the specimen is also increased. Hence it is clear that triple blending contributes towards a stronger and impermeable concrete. 
Impact And Permeability Properties of Fibrous Triple Blended Self Compacting Concrete.

Table4: Results Of Average Compressive Strength (N/Mm2) After Specified Number Of Blows Of M40 Grade

\begin{tabular}{|c|c|c|c|c|c|c|c|c|}
\hline COMBINATION & $\begin{array}{l}\% \text { of } \\
\text { Steel }\end{array}$ & $\begin{array}{l}\text { Aspect } \\
\text { ratio }\end{array}$ & $\begin{array}{l}\text { ZERO } \\
\text { BLOWS } \\
\end{array}$ & $\begin{array}{l}50 \\
\text { BLOWS }\end{array}$ & $\begin{array}{l}100 \\
\text { BLOWS }\end{array}$ & $\begin{array}{l}150 \\
\text { BLOWS }\end{array}$ & $\begin{array}{l}200 \\
\text { BLOWS }\end{array}$ & REMARKS \\
\hline IP(a) & $\mathbf{0}$ & -- & 60.5 & 58.0 & 55.0 & 49.50 & - & $\begin{array}{l}\text { Failed at } \\
167 \& 180\end{array}$ \\
\hline IP(b) & $\mathbf{0}$ & -- & 62.53 & 61.83 & 59.04 & 54.57 & 49.87 & - \\
\hline IP1 & 0.1 & 10 & 47.19 & 46.59 & 44.40 & 41.94 & 35.24 & - \\
\hline IP2 & 0.1 & 15 & 47.76 & 46.96 & 45.44 & 43.08 & 40.00 & - \\
\hline IP3 & 0.1 & 20 & 57.94 & 56.54 & 54.96 & 52.90 & 41.71 & - \\
\hline IP4 & 0.1 & 25 & 65.24 & 61.20 & 58.70 & 53.70 & 49.83 & - \\
\hline IP5 & 0.2 & 10 & 69.60 & 63.94 & 61.26 & 58.92 & 51.79 & - \\
\hline IP6 & 0.2 & 15 & 71.07 & 69.62 & 67.52 & 63.16 & 52.64 & - \\
\hline IP7 & 0.2 & 20 & 75.14 & 74.52 & 73.90 & 70.22 & 59.64 & - \\
\hline IP8 & 0.2 & 25 & 78.71 & 76.84 & 74.49 & 71.37 & 61.39 & - \\
\hline IP9 & 0.3 & 10 & 79.40 & 77.70 & 76.41 & 72.86 & 62.69 & - \\
\hline IP10 & 0.3 & 15 & 79.50 & 78.37 & 77.81 & 73.17 & 64.05 & - \\
\hline IP11 & 0.3 & 20 & 79.80 & 78.80 & 78.50 & 73.60 & 65.40 & - \\
\hline IP12 & 0.3 & 25 & 80.01 & 78.93 & 78.64 & 74.60 & 65.80 & - \\
\hline IP13 & 0.4 & 10 & 80.12 & 79.30 & 78.80 & 75.02 & 67.30 & - \\
\hline IP14 & 0.4 & 15 & 80.66 & 79.87 & 79.30 & 76.60 & 68.70 & - \\
\hline IP15 & 0.4 & 20 & 81.06 & 80.99 & 79.40 & 77.50 & 69.92 & - \\
\hline IP16 & 0.4 & 25 & 82.50 & 81.90 & 80.32 & 78.06 & 70.10 & - \\
\hline
\end{tabular}

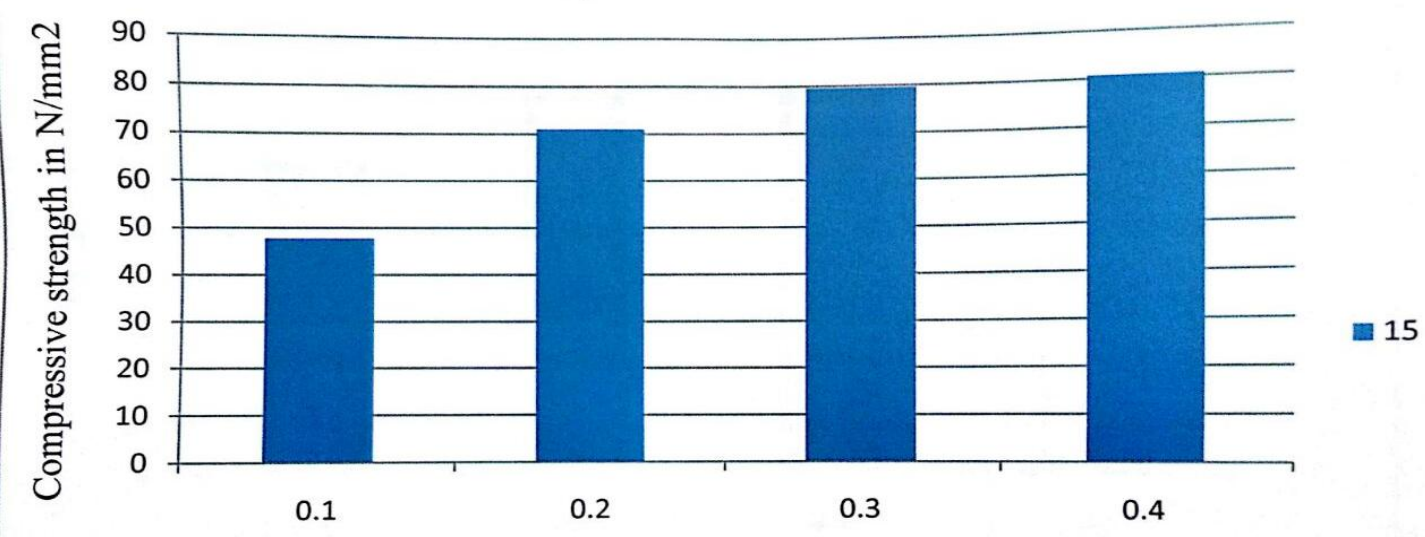

Percentage of Steel Fibre

Fig1: Results of Compressive strength for Aspect Ratio 15 after Zero Blows

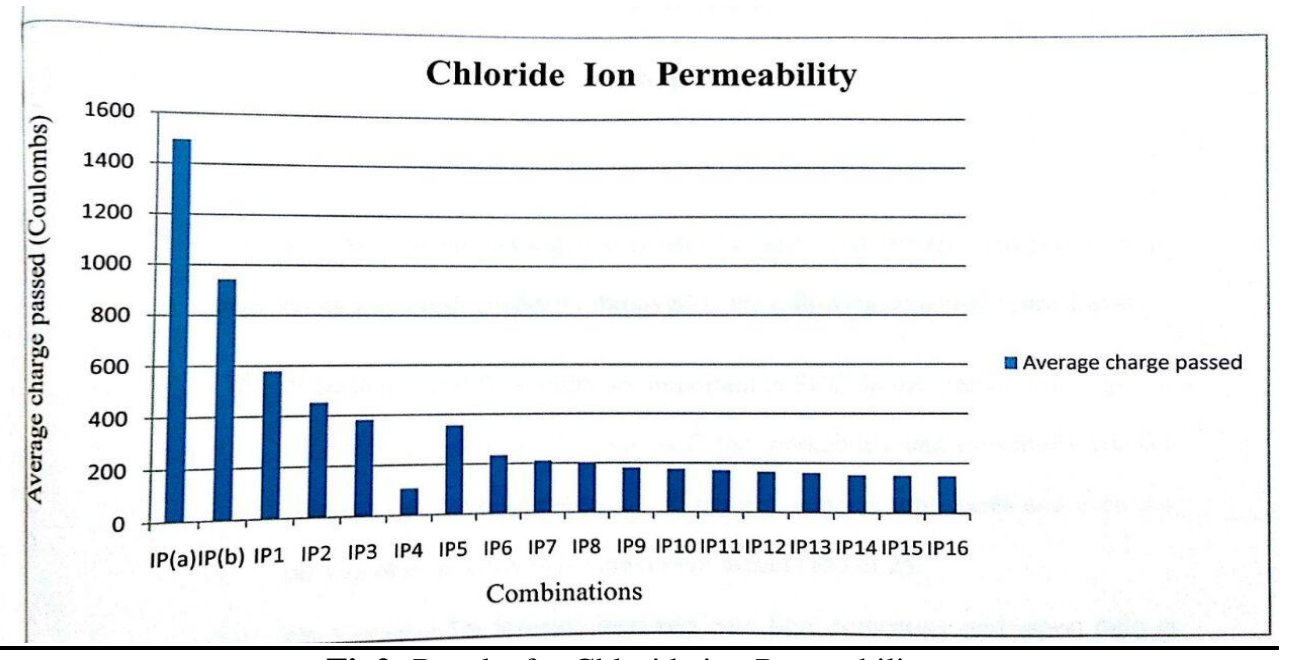

Fig2: Results for Chloride ion Permeability 


\subsection{Advantages Of Triple Blending}

Flyash contribute towards workability, durability.. etc, benefits in concrete. If percentage of fly ash used as replacement to OPC is higher the 28 days strength will reduced. Hence an optimum percentage of $20 \%$ fly ash was used to give good workability and imperability. CSF contributes towards strength increase also besides the other beneficial properties. Hence $20 \%$ fly ash,10\% CSF were used to produce triple blended concrete in the present investigation to give optimum benefits.

\subsection{Influence of steel fibers}

As already discussed, it is clear that addition of steel fiber resulted in higher compressive strength and "very low" permeability. This is because that steel fibers in the matrix bind together al the concrete particles without giving scope for formation of micro pores in the concrete. Fibers also contribute towards the prevention of shrinkage cracks in concrete.It is to be noted that while using steel fibers in SCC the percentage as well as aspect ratio are to be maintained so as not to affect the flow of concrete. If necessary percentage of superplastizer and VMA are to be adjusted.

\subsection{Over All Comments}

The main requirement of SCC is flowability. When the high strength concrete mixes are used for SCC the percentage of chemical admixtures may become more to maintain flow ability. When fiber reinforcement is employed, the percentage of chemical admixtures, percentage of fibers and aspect ratio of fiber are to be appropriately adjusted, to arrive at an optimum mix. In the present experimental investigation, fibrous triple blended M40 concert mix is developed possessing optimum properties.

\section{Conclusions}

Based on the experimental investigation conducted on impact strength and permeability characteristics of triple blended fibrous SCC following conclusions are drawn

1. Workability and flowability are important in SCC. In the present investigation on triple blended fibrous SCC, the workability and flowability are not affected due to presence of $30 \%$ mineral admixtures and even with $0,4 \%$ of steel fibre with a maximum aspect ratio of 25 .

2. The compressive strength increases with fiber percentage and aspect ratio in the present triple blended fibrous SCC. At $0.4 \%$ of steel fibre with an aspect ratio of 25 the compressive strength is maximum and nearly $35 \%$ more compared to the reference mix.

3. It is necessary to conduct the impact strength to know the influence of fibre on the strength properties of concrete. As the number of blows given in drop hammer test are increased, the compressive strength gets decreased.

4. At steel fibre percentage of $0.2 \%$ with aspect ratio 15 , the compressive strength is reduced by nearly $3 \%, 5 \%, 10 \%$, and $30 \%$ with $50,100,150$ and 200 blows respectively.

5. As thenumber of blows are increased in drop weight impact test, the residual compressive strength gets gradually decreased.

6. In the combination consisting of $0.4 \%$ steel with 25 aspect ratio, the reduction in compressive strength from 0 to 200 blows is $15 \%$

7. Using mineral admixtures as partial replacement to cement in SCC reduces the permeability.

8. Small percentage of steel fibers with low aspect ratio also contribute towards making a denser concrete with lower permeability.

9. The permeability of triple blended fibrous SCC with $0.4 \%$ steel and a maximum aspect ratio of 25 is decreased when compared to the reference concrete by nearly $90 \%$.

10. Permeability of concrete by the RCPT is more reliable and accurate compared to other conventional concrete.

\section{Acknowledgment}

The authors sincerely thank the authorities of Vasavi College of Engineering, Hyderabad, for extending the laboratory facilities in conducting the present experimental investigation.

\section{References}

[1] ACI 544, IR-96, State-of-the-art report on fibre reinforced concrete, Farmington Hills, Michigan: American concrete institute, 1996.

[2] IS 10262: 2009 - Concrete mix proportioning - guidelines bureau of Indian Standards, New Delhi.

[3] Bentur, A. and Mindess, S. Fibre reinforced cementitious composites, London: Elsevier, 1990.

[4] Bui, Van K. And Attiogbe, Emmanuel. Degussa Admixtures, Inc., Seminar at UM on October 27, 2005.

[5] Brein Pamlson, Sanitary General, EFNARC. Specifications and Guidelines for Self-Consolidating Concrete", February 2002.

[6] Brein Pamlson, EFNARC, Secretary General, Specifications and guidelines for Self Compacting Concrete.

International Conference on Recent Innovations in Civil \& Mechanical Engineering $\quad$ 46| Page [i-CAM2K16] DOI: 10.9790/1684-16053014147 
[7] Johnston, C.D.," Fiber- Reinforced Cements and Concrete", Gordon and Breach Science Publishers, Amsterdam, 2001.

[8] Narayanan, R., Kareem-Planjian, A.S,"Factors influencing the workability of steel-fiber reinforced concrete", Concrete, Part 1: vol.16, No.10, 1982, pp.45- 48, part 2: Vol. 17, No.2, 1982, pp.43-44

[9] Okamura, H, "Self Compacting High Performance Concrete," Concrete International, pp.50-54(1997).

[10] Okamura, H., y Ouchi, M.," Self Compacting concrete development, present use and future", $1^{\text {st }}$ International RILEM Symposia on Self Compacting Concrete, Edited by A. Skarendahi y O. Petersson, Editorial RILEM publications S.A.R.L., Cachan, Francia, 1999.

[11] Ozawa, K., "Development of high performance concrete based on the durability design of concrete structures", EASEC-2, Vol.1 pp.445-450(1989)

[12] Petersson, O., Billiberg, P. y van, B.K., A" model for self-compacting concrete, production Methods and Workability of Concrete", Edited by P.J.M. Bartos, D.L. Marrs y D.J. Cleand, Editorial: E\&FN Spon, Londres, 1996. 